\section{Section Editor}

Mitchell S.V. Elkind, MD, MS

G. Tsivgoulis, MD

K. Vadikolias, MD

N. Courcoutsakis, MD

I. Heliopoulos, MD

E. Stamboulis, MD

C. Piperidou, MD

Correspondence \& reprint requests to Dr. Tsivgoulis: tsivgoulisgiorg@yahoo.gr

\title{
Teaching NeuroImages: \\ Differential diagnosis of scapular winging
}

Figure 1 Right scapular winging caused by weakness of ipsilateral trapezius (A-C: arrow depicts the upper trapezius atrophy; D: arrow depicts the atrophy in upper trapezius and asterisk depicts the normal infraspinatus on coronal T1-weighted right shoulder MRI), rhomboids (E-G: arrow and asterisk depict atrophy of infraspinatus and rhomboids, respectively), and serratus anterior $(\mathrm{H}$ : arrow depicts the contracting lower trapezius causing medial displacement of scapula)
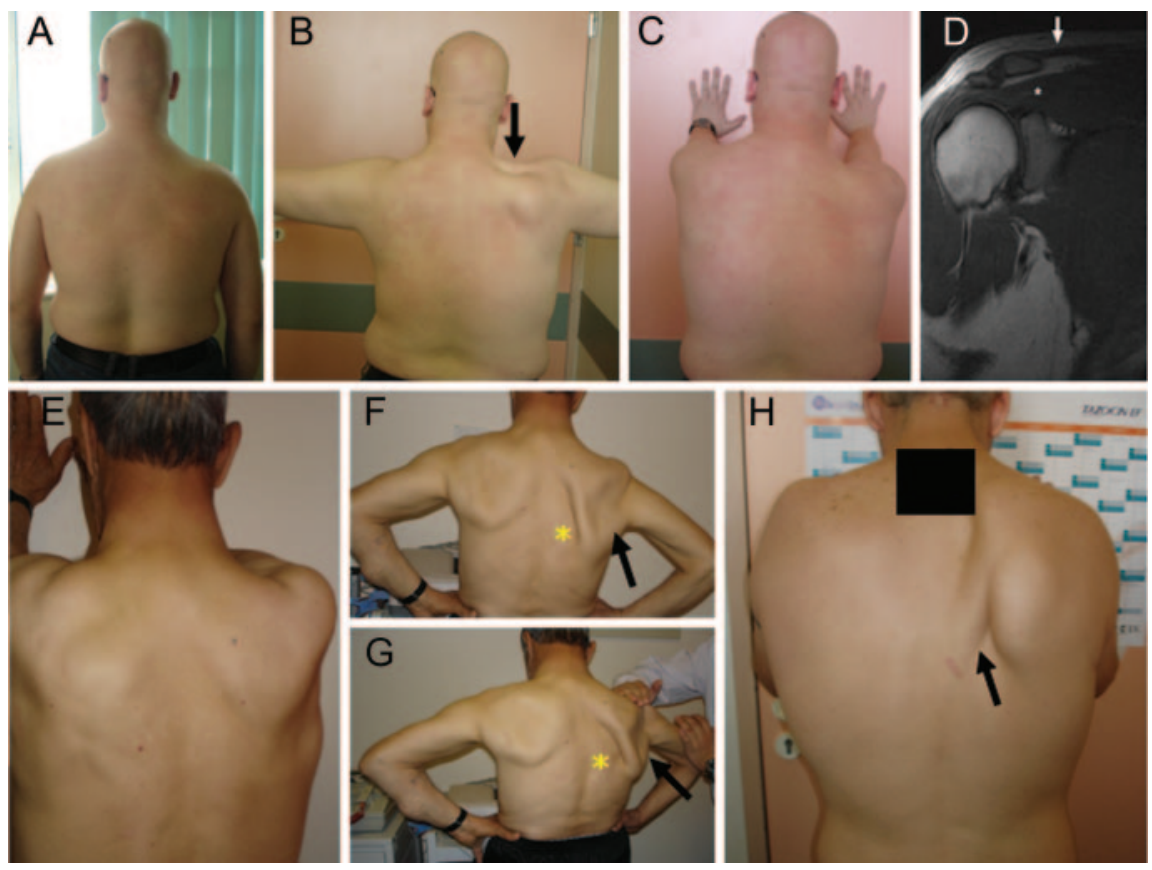

Scapular winging (SW) is caused by weakness of trapezius, rhomboids, and serratus anterior muscles. The different patterns of scapular movement among these causes assist in the differential diagnosis and are illustrated in the 3 described cases (table e- 1 on the Neurology ${ }^{\circledR}$ Web site at www.neurology.org). ${ }^{1,2}$

Case 1 (figure 1, A-C) presented with right SW (lateral displacement of superior angle that became evident at arm abduction) due to upper trapezius weakness and atrophy that is also evident on shoulder MRI (figure 1D and figure e-1). Case 2 (figure 1, E-G) had right SW (lateral displacement of inferior angle that was accentuated when the patient pushed his elbow backwards against resistance) due to rhomboids weakness. Case 3 (figure 1H) had right SW (medial displacement of scap- ula that was enhanced during forward arm flexion) due to serratus anterior weakness.

\section{AUTHOR CONTRIBUTIONS}

Dr. Tsivgoulis: study design, drafting and revising the manuscript. Dr. Vadikolias: data collection, critical comments during manuscript revision. Dr. Courcoutsakis: data collection, critical comments during manuscript revision. Dr. Heliopoulos: data collection, critical comments during manuscript revision. Dr. Stamboulis: drafting and revising the manuscript. Dr. Piperidou: drafting and revising the manuscript.

\section{REFERENCES}

1. Meininger AK, Figuerres BF, Goldberg BA. Scapular winging: an update. J Am Acad Orthop Surg 2011;19:453-462.

2. Martin RM, Fish DE. Scapular winging: anatomical review, diagnosis, and treatments. Curr Rev Musculoskelet Med 2008;1:1-11.
Supplemental data at www.neurology.org
From the Departments of Neurology (G.T., K.V., I.H., C.P.) and Radiology and Medical Imaging (N.C.), Democritus University of Thrace,

University Hospital of Alexandroupolis, Alexandroupolis; and Second Department of Neurology (E.S.), University of Athens, School of Medicine, "Attikon" University Hospital, Athens, Greece.

The authors report no disclosures relevant to the manuscript. Go to Neurology.org for full disclosures. 


\section{Neurology}

\section{Teaching NeuroImages: Differential diagnosis of scapular winging}

G. Tsivgoulis, K. Vadikolias, N. Courcoutsakis, et al.

Neurology 2012;78;e109

DOI 10.1212/WNL.0b013e3182518361

\section{This information is current as of April 23, 2012}

\section{Updated Information \&}

Services

Supplementary Material

\section{References}

Citations

Subspecialty Collections

Permissions \& Licensing

Reprints including high resolution figures, can be found at: http://n.neurology.org/content/78/17/e109.full

Supplementary material can be found at: http://n.neurology.org/content/supp1/2012/04/22/78.17.e109.DC1

This article cites 2 articles, 0 of which you can access for free at: http://n.neurology.org/content/78/17/e109.full\#ref-list-1

This article has been cited by 3 HighWire-hosted articles: http://n.neurology.org/content/78/17/e109.full\#\#otherarticles

This article, along with others on similar topics, appears in the following collection(s):

Clinical neurology examination

http://n.neurology.org/cgi/collection/clinical_neurology_examination

Information about reproducing this article in parts (figures,tables) or in its entirety can be found online at:

http://www.neurology.org/about/about_the_journal\#permissions

Information about ordering reprints can be found online:

http://n.neurology.org/subscribers/advertise

Neurology ${ }^{\circledR}$ is the official journal of the American Academy of Neurology. Published continuously since 1951, it is now a weekly with 48 issues per year. Copyright Copyright $@ 2012$ by AAN Enterprises, Inc.. All rights reserved. Print ISSN: 0028-3878. Online ISSN: 1526-632X.

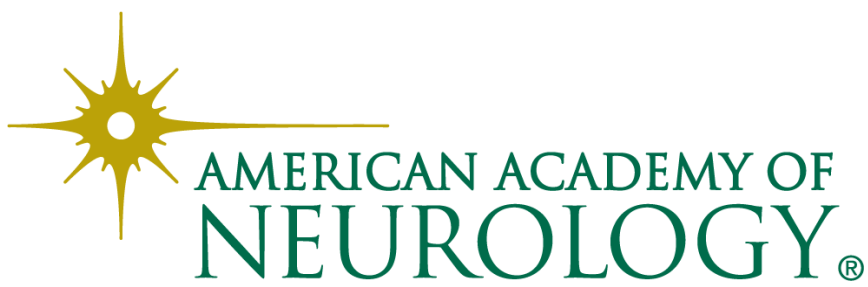

